\title{
Adenovirus Viral Load Measurement
}

National Cancer Institute

\section{Source}

National Cancer Institute. Adenovirus Viral Load Measurement. NCI Thesaurus. Code C98705.

The determination of the amount of adenovirus viral load present in a sample. 